\section{A case study on the development of representative sampling procedure to determine mercury levels in a lot of tuna caught by static trap}

\author{
Pierluigi Piras, ${ }^{1}$ Antonio Assaretti, ${ }^{1}$ \\ Gianuario Fiori, ${ }^{2}$ Andrea Sanna, ${ }^{2}$ \\ Giannina Chessa ${ }^{2}$
}

${ }^{1}$ Health Protection Service of Sardinia, Southern Prevention Department, Cagliari; ${ }^{2}$ Environmental Chemistry and Toxicology Laboratory, Zooprophylactic Institute of Sardinia, Sassari, Italy

\begin{abstract}
Mercury contamination in fish products, and in large pelagic predatory fish in particular, is a remarkable food safety issue that affects fish industry. A lot made up by Bluefin tunas caught at Porto Paglia - in the south-western coast of Sardinia - was subject to several sessions of fish meat official sampling, as disputable results of mercury level determination suggested a potential non-compliance to maximum allowable limit. Local competent Veterinary Service reviewed the sampling procedure introducing more rigorous details including the identification of a specific muscular portion as sampling site, after having taken into account both statutory provisions laid down by Regulation (EC) No 333/2007 and available scientific evidence on variables affecting uneven distribution of mercury across tuna carcasses. This case-study aims to provide an initial contribution in order to ensure an appropriate and representative field sampling protocol of tuna lots that are to be analysed for mercury content.
\end{abstract}

\section{Introduction}

Mercury is a toxic metal that is released into the environment both from natural and anthropogenic sources (EFSA, 2012). The primary dietary source of human mercury exposure is seafood that constitutes up to an estimated $95 \%$ of total dietary mercury intake for most populations (Balshaw et al., 2008). The total $\mathrm{Hg}(\mathrm{tHg})$ content of fish consist of a combination of several $\mathrm{Hg}$ species and methyl $\mathrm{Hg}(\mathrm{MeHg})$ is considered the most toxic form, which is also the most abundant $\mathrm{Hg}$ species $(75-100 \%$ of $\mathrm{tHg}$ ) in fish meat (Bosch et al., 2016). As it is generally assumed that almost $100 \%$ of $\mathrm{tHg}$ is present as $\mathrm{MeHg}$, official samples are only tested for $\mathrm{tHg}$. Routine monitoring determination of $\mathrm{MeHg}$ concentrations in addition to the current $\mathrm{tHg}$ analysis procedure would require $\mathrm{Hg}$ speciation and thus additional analyses with associated equipment and costs (Bosch et al., 2016).

In the European Union, maximum allowable levels (MAL) of $\mathrm{tHg}$ contamination in commercial fish are laid down in point 3.3.1 of Annex to Regulation (EC) No $1881 / 2006$ which states $0.50 \mathrm{mg} / \mathrm{kg}$ wet weight (w.w.) for most fishes. However, those species that are recognized as naturally accumulating elevated levels of mercury, such as large, long-lived, fish-eating species including tuna, are exempt from that generic maximum allowable level and a $1.0 \mathrm{mg} / \mathrm{kg}$ w.w MAL is laid down in point 3.3.2 of Annex to mentioned regulation. Most of the research on mercury levels in fish has focused on large predatory fish such as tuna, given that mercury is known to bioaccumulate along food chain (Balshaw et al., 2008).

These studies have reported wide variations of mercury concentrations in fish from different geographical locations (Rasmussen et al., 2005). In a study carried out in 1999 on several trawl surveys in the Ionian Sea (Storelli et al., 2002), several examples of Thunnus thynnus (Linnaeus, 1758) were grouped by size and muscle tissue samples were taken from the anterior portion of the carcass by a transverse dissection near the dorsal fin. Concentration of $\mathrm{tHg}$ was found to average $1.18 \pm 0.85$ $\mathrm{mg} / \mathrm{kg}$ w.w. and levels above MAL were determined in more than half of samples. Another study carried out in above species in Messina strict some years later (Licata et al., 2005), found that $\mathrm{Hg}$ levels in fish meat were higher than MAL (average $3.03 \pm 0.55$ $\mathrm{mg} / \mathrm{kg}$ w.w., even though the location of sampled muscle was not specified), highlighting a toxicological risk to consumer.

Variation in fish muscle mercury concentrations may be the result, in varying degrees, of variability associated with the species themselves (age, size, physiology, diet), and of other influences, such as mercury biogeochemistry (Licata et al., 2005). More recent studies revealed that $\mathrm{Hg}$ concentrations in Thunnus thynnus declined significantly over an 8-year period (from 2004 to 2012). Notably, this decrease parallels comparably reduced anthropogenic $\mathrm{Hg}$ emission rates in North America and North Atlantic atmospheric $\mathrm{Hg}$ concentrations during this period, suggesting that recent efforts to decrease atmospheric $\mathrm{Hg}$ loading have rapidly propagated up
Correspondence: Pierluigi Piras, Health Protection Service of Sardinia, Southern Prevention Department, Cagliari, Italy.

Tel.: +39.3392056525.

E-mail: pirasp@tiscali.it

Key words: Bluefin tunas, Fish meat sampling, Mercury determination.

Contributions: the authors contributed equally.

Conflict of interest: the authors declare no potential conflict of interest.

Funding: none

Received for publication: 12 March 2019

Revision received: 19 September 2019.

Accepted for publication: 25 September 2019

This work is licensed under a Creative Commons Attribution-NonCommercial 4.0 International License (CC BY-NC 4.0).

(C) Copyright: the Author(s), 2019

Licensee PAGEPress, Italy

Italian Journal of Food Safety 2019; 8:8165

doi:10.4081/ijfs.2019.8165

marine food webs to a commercially important species as tuna (Lee et al., 2016).

The muscular tissue is the primary reservoir for bioavailable mercury and is also the portion really consumed. Consequently, mercury concentrations in fish meat have important implications for consumer health and risk assessment (Balshaw et al., 2008). However, it is not possible to test whole fillets for mercury content in all fish species, particularly when considering large fishes, such as tuna. In this case, point B.2.3. of Annex to Regulation (EC) No 333/2007 (European Commission, 2007) lays down that it is to be collected only a small section (or incremental sample) of tissue, generically taken from "the middle part of the fish", whose exact location may depend on practical and economic convenience as it is necessary to proceed according to point B.2.2. of mentioned Annex (i.e. applying a method of sampling that not causes unacceptable commercial consequences).

Moreover, this practice is fuelled by an assumption that mercury is evenly distributed throughout all muscular tissues, even though there are very few published studies on his distribution across carcass (Balshaw et al., 2008). In the fish muscular tissue, mercury is believed to form coordination complex with thiol group of substance, such as cysteine, and as such is predominantly found in association with the 
protein fraction of tissues (Balshaw et al., 2008). In fact, from $71 \%$ to $89 \%$ of mercury in the muscular tissue of bluefin tuna is found in association with myofibrillar and sarcoplasmic protein fractions (Itano and Sasaki, 1983). These studies found that $\mathrm{Hg}$, especially $\mathrm{MeHg}$, may distribute within muscular cells according to the reactivity of relative $\mathrm{SH}$ groups among different proteins (sarcoplasmic protein, myofibrillar protein, actomyosin and subactomyosin). This depends upon the state of the protein components, sarcoplasmic protein in particular, which are affected by the muscle temperature (Itano and Sasaki, 1983).

$\mathrm{SH}$ groups in proteins are classified into the following types according to their reactivity (Itano and Sasaki, 1983): a freely reacting type, a sluggish type and a masked type. It is believed that when proteins become insoluble, $\mathrm{SH}$ groups become hidden inside or the content of reactive $\mathrm{SH}$ groups decreases due to S-S bonding. This corresponds to the decrease of reactive $\mathrm{SH}$ groups in sarcoplasmic protein due to increase of temperature. In fact, it is important to consider that in large pelagic fish species such as tuna, composition of the various muscles and anatomical sections can vary, as these fish have two very distinct muscle types (dark and white muscle), which have different functions (dark = slow, continuous movement, generally aerobic; white $=$ fast, sudden movement, with a tendency to be anaerobic) and chemical compositions (Bosch et al., 2016). Since Hg forms complexes with thiol group in muscle tissue, the presence of such different muscle types with different protein compositions can therefore result in variation in heavy metal accumulation and concentration across the fish carcass (Bosch et al., 2016).

The inter- and intra-muscle type (dark and white) variability in $\mathrm{Hg}$ accumulation in tuna suggests that potential biases can exist when subsampling fish to determine representative content as $\mathrm{tHg}$ concentrations are higher in dark muscle than in white muscle, as found in Yellowfin tuna (Bosch et al., 2016). Sampling from dark muscle will therefore result in higher $\mathrm{tHg}$ readings and $\mathrm{Hg}$ toxicity of the fish carcass could therefore be overestimated (Bosch et al., 2016). Consequently, systematic differences in $\mathrm{Hg}$ among different muscle types need to be taken into account in the sampling protocol in order to obtain representative and accurate $\mathrm{Hg}$ levels determination (Bosch et al., 2016). As the two muscle types have a different function, particularly in Scombrids, muscle-tissue-specific enzymatic attributes and the distribution of the red muscle in the swimming musculature, are to be taken into account (Sharp and Pirages, 1978).
Moreover, the placement of red muscle assessment involves hypothesis about distribution of species in the oceans with respect to temperature, size and swimming activity levels (Sharp and Pirages, 1978). In fact, true tropical species of the genus Thunnus have red muscle masses contiguous with both the lateral surface and the vertebral centra, showing a relatively primitive arrangement compared to the internal arrays of those tunas known to extend into or prefer cooler habitats (Sharp and Pirages, 1978). Internalization of red muscle in species preferring cooler water is most likely an adaptation which permits keeping a "tropical" red muscle temperature. Out of the overall eight species of Scombrids of the genus Thunnus (Collette and Nauen, 1983; Collette et al., 2001), those living in the Atlantic Ocean (Tiews et al., 1963; Schaefer et al., 1963) that show a primitive configuration of red muscle, include intertropical cosmopolite species such as $T$. albacares (Bonnaterre, 1788), denominated "Yellowfin tuna", and T. obesus (Lowe, 1839), denominated "Bigeye tuna". Temperate and cold climate species such as T. thynnus of Northern Atlantic - the specific focus of this case-study - denominated also "Northern bluefin tuna", and T. maccoyii (Castelnau, 1872), denominated "Southern bluefin tuna", are circumtropical austral species that constitute the most recent group of tunas, living in habitats ranging from permanently extreme cold (adult $T$. maccoyii) to more various climates, such as T. thynnus (from $5^{\circ} \mathrm{C}$ to $30^{\circ} \mathrm{C}$ ). Inner body temperature of these exemplifying species was found to be even $20^{\circ} \mathrm{C}$ above the environmental one (Sharp and Pirages, 1978). In tuna, as large migratory fish, continuous swimming is guaranteed by the dark muscle that ensures the tail thrust (Bosch et al., 2016).

The observed variation of $\mathrm{Hg}$ content in muscular tissue across tuna carcass determines a certain degree of uncertainty when comparing results of different studies that ambiguously describe tissue samples related to position, e.g. samples taken from the dorsal loin area above the lateral line or just above the caudal peduncle (Rasmussen et al., 2005). In order to improve the comparability of results, it is recommendable that muscle samples are identified by location and tissue cut (Balshaw et al., 2008). However, Regulation (EC) No $333 / 2007$ itself lacks of details as which precise carcass sites are to be sampled in fishes characterized by a very large size.

Besides white and dark muscle, the edible muscular tissue of tuna is placed on the market as different cuts distinguishable by location, structure, lipid content and colour. Examination of the composition (protein, moisture, lipid, ash) of tuna tissues indicates that there are remarkable differences between muscular cuts both in terms of the lipids proportion and of proteins. In this regard, $\mathrm{tHg}$ concentration and lipid content were measured (Balshaw et al., 2008) both in aggregate sample of all edible tissues and in each commercial tissue cut of Southern bluefin tuna. Regardless of cutting of tuna according to traditional manners in different populations that can lead to a wide variety of cuts, the commercial cuts of tunas (Figure 1) are generally categorized as: upper loin ("schienale" in Italian, "chu-toro" in japanese), lower loin ("bòdano" in Italian, "akami" in japanese), belly flap ("ventresca" in Italian, "o-toro" in japanese), black tail ("codella nera" in Italian, "seshimo" in

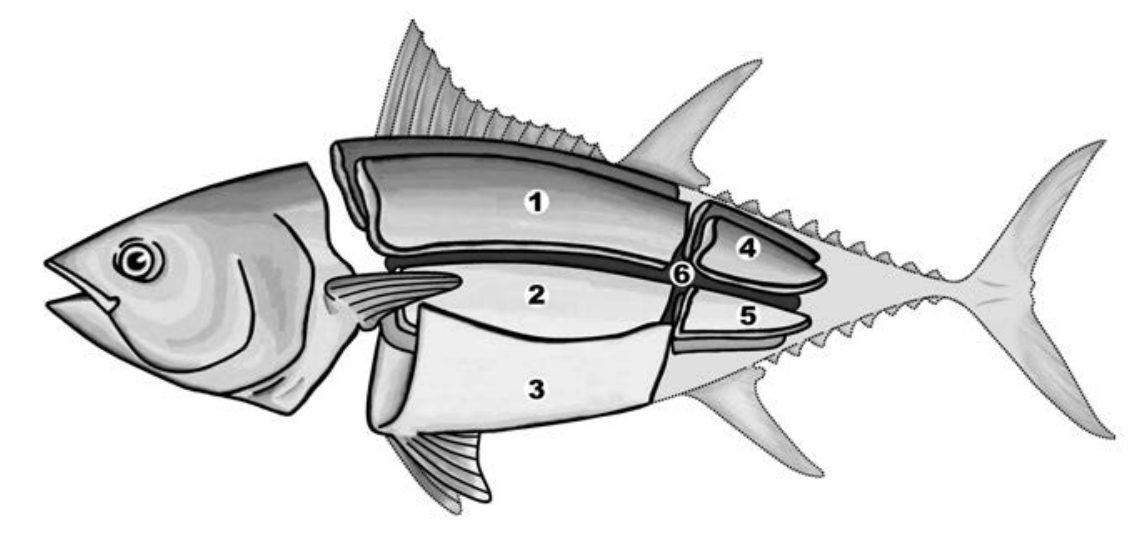

Figure 1. Commercial cuts scheme according to processing of bluefin tuna caught in the traditional static tuna traps in the south-western coast of Sardinia (Sulcis-Iglesiente), reporting: 1) the "schienale" or upper loin; 2) the "bòdano" or lower loin; 3) the "ventresca" or belly flap; 4) the "codella nera" or black tail; 5) the "codella bianca" or white tail, and 6) the "buzzonaglia" o dark meat. 
japanese), white tail ("codella bianca" in Italian, "harahimo" in japanese) and the dark meat ("buzzonaglia" in Italian, "chiai" in japanese) characterized by a dark red nearly dark brown - colour (actually, the "buzzonaglia" is not a real muscle cut as it is obtained from dark muscle tissue, abundantly filled with blood, alongside fishbone). It is acknowledged that $\mathrm{Hg}$ concentration in tissue cuts and in aggregate samples constantly decrease as lipid content rises in each fish, despite differences in fish size. Therefore, lipid accumulation appears to have a dilution effect on mercury already associated with fish tissues (Balshaw et al., 2008). The affinity of lipid for certain tissue cuts (e.g. belly flap) over others (e.g. lower loin) will result in cross-carcass variation in the $\mathrm{Hg}$ concentration of fish muscular tissue with clear implications for mercury advisory statements and verification of compliance by the competent authorities. In fact, sampling from the front abdominal white muscle in tuna could result in under-representation of the $\mathrm{Hg}$ content in the rest of the carcass (Balshaw et al., 2008). Consequently, a critical factor is represented by anatomic location of muscle that undergoes sampling for analyses.

According to the development of a conceptual model (Maher et al., 1994) in the planning framework of a sampling program, the potential sources of error that contribute to the total error are to be taken into account. Such sources include both the analytical error, and the sampling and sub-sampling errors. On official control grounds minimizing laboratory analytical error is usually emphasized regardless of sampling errors that often are prevalent, though. Therefore, if samples are the basis to verify if large size tuna are fit for human consumption (and to support any possible legal action), it is important that this matter is first dealt with (Maher et al., 1994): where was the sample exactly collected from?

\section{Case Report}

As reported in the necessarily extensive introduction, $\mathrm{Hg}$ contamination in fish products, and in large pelagic predatory fish in particular, is a remarkable food safety issue that affects fishery, such as the last static tuna traps still in active in the southwestern coast of Sardinia (Sulcis-Iglesiente). In the traditional static tuna traps (Figure 2) of Porto Paglia, Capo Altano and Carloforte, the catching of Thunnus thynnus still represents both a support to local fish industry (Figures 3 and 4) and an undisputable traditional activity of local population.

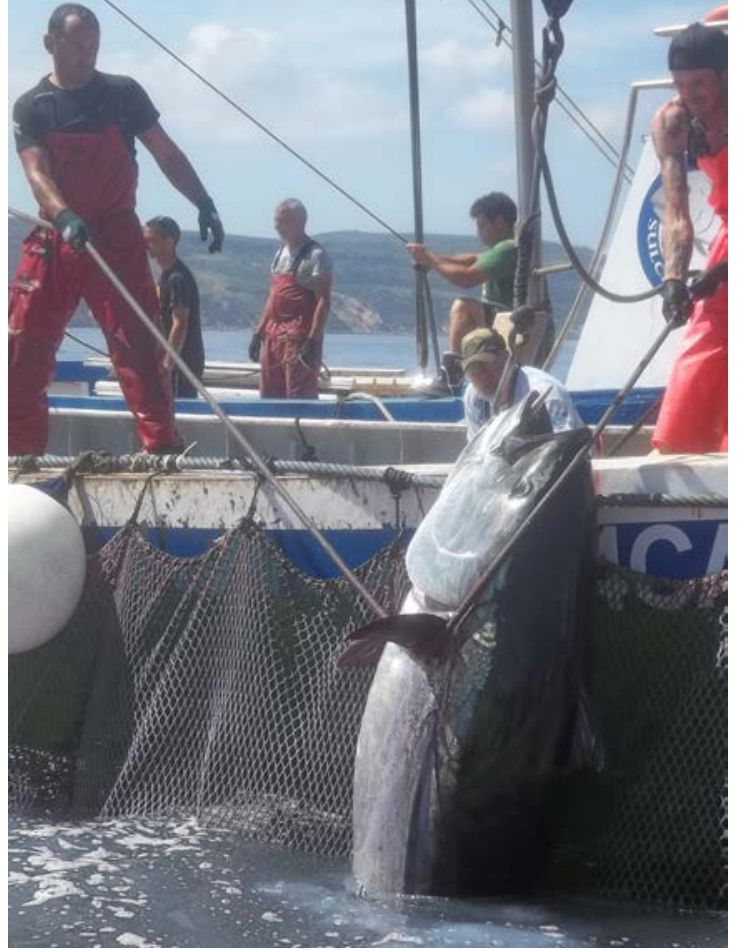

Figure 2. Bluefin tuna catching and bringing on board of ice provided boats in the traditional static tuna traps of Porto Paglia, in the south-western coast of Sardinia (SulcisIglesiente).

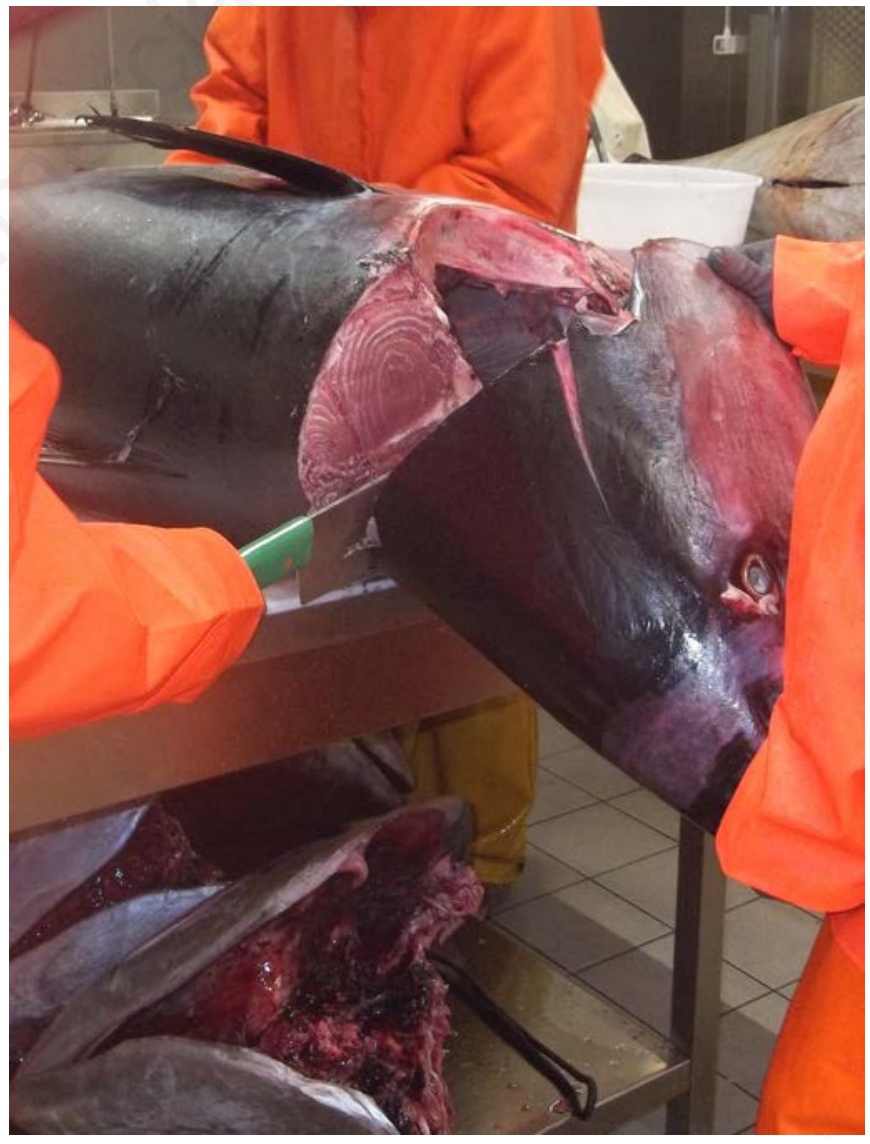

Figure 3. Initial processing step - always at Tonnare Sulcitane's establishment (in Portoscuso, South-West of Sardinia) - of bluefin tuna already bleeded (and having gill arches removed) and eviscerated. 
Official sampling was carried out in two sessions, the first at the end of May 2017 on the overall quantity stocked in the establishment freezing room (at temperature of $-50^{\circ} \mathrm{C}$ ) and the second in November 2017 only on the lot identified as BCD n. IT6001067 - ATEV 2ITA0006-13 made up by tunas caught at Porto Paglia. Subsequent laboratory analysis determined a $\mathrm{Hg}$ content exceeding statutory maximum level, in the amount of $2.34 \pm 0.65$ and $2.31 \pm 0.90 \mathrm{mg} / \mathrm{kg}$ w.w., respectively, leading to the precautionary seizure of the lot. However, such result was not confirmed neither by the analysis - dated December 2017 - carried out by a private laboratory on behalf of the food business operator that reported a $\mathrm{Hg}$ content below maximum level $(0.47 \mathrm{mg} / \mathrm{kg}$ w.w. $)$, nor by the revision analysis carried out by the National Institute of Health that determined a significantly different $\mathrm{Hg}$ level from previous analysis, even if still exceeding the statutory maximum level $(1.4 \pm 0.1 \mathrm{mg} / \mathrm{kg}$ w.w.). Since the competent authority's reliability in carrying out official controls was questioned, it was hypothesized that the remarkable measurement uncertainty was likely to be attributable to an incorrect and inappropriate sampling procedure. It was necessary to examine in depth the variables affecting the probably notable uneven distribution of $\mathrm{Hg}$ in different lots and across each single carcass of tuna, in order to adopt an appropriate procedure allowing an effectively representative, reliable and reproducible collection of samples from the entire lot to verify compliance of $\mathrm{Hg}$ content.

The mentioned lot of tunas caught at Porto Paglia was sampled again in May 2018. The sampling procedure consisted in the subdivision of the lot into two sublots, on the basis of a fish size criterion. Incremental samples were taken from each sublot rigorously identifying the upper loin in the middle part of the fish as sampling location, and then each group of incremental samples was homogenised in an aggregate sample. Pre-analysis procedure as laid down in points B.1.6. and C.2.4. of Annex to Regulation (EC) No 333/2007, were followed for defence and referee purposes.

Determination of $\mathrm{tHg}$ in each aggregate sample, was performed according to EPA 6020B Inductively Coupled Plasma-Mass Spectrometry method for instrumental determination and EPA 3052 method for sample preparation. Analytical method was validated in compliance with UNI/EN/ISO $17025 / 2005$. The limit of quantification (LoQ) equal to $0.010 \mathrm{mg} / \mathrm{kg}$. Briefly a subsample of homogenized sample in the amount of $1 \mathrm{~g}$, was mineralized in microwave oven system at temperature and pressure fixed. Total Mercury was determined by Agilent 7500CE ICP-MS. Concentrations were determined by interpolation of reading signal with calibration curves using ${ }^{202} \mathrm{Hg}$, as isotope of element quantification and ${ }^{209} \mathrm{Bi}$ as internal standard element to compensate matrix and signal drift. The quality control of the data produced was verified e controlled using Certified Reference Materials ERM-BB422 fish muscle $(0.601 \pm 0.030 \mathrm{mg} / \mathrm{kg})$ and BCR463 tuna fish $(2.85 \pm 0.16 \mathrm{mg} / \mathrm{kg})$. Total Mercury were determined on the two sublots sampled as described. Concentrations levels were $0.97 \pm 0.37 \mathrm{mg} / \mathrm{kg}$ for the smaller size tuna sub-lot sample and $0.84 \pm 0.33$ $\mathrm{mg} / \mathrm{kg}$ for the sub-lot of the larger ones. According to the procedure reviewed by the competent Veterinary Services of South Sardinia Prevention Department, the two sub-lots samples were found compliant to the statutory maximum level.

\section{Discussion}

In order to allow the collection of representative samples, the potential sources of variability in the data must be considered: site, selection, frequency and replication must account for the expected variability (Maher et al., 1994). All sampling plans require a quality assurance program to identify, measure and control errors, so as to minimize the total error of the estimate of interest by controlling the magnitude of the individual error components (i.e. sample and sub-sample, and analytical error).

With regard to this specific case-study, it is first to be taken into account that $\mathrm{Hg}$ is not uniformly distributed in muscular tissue

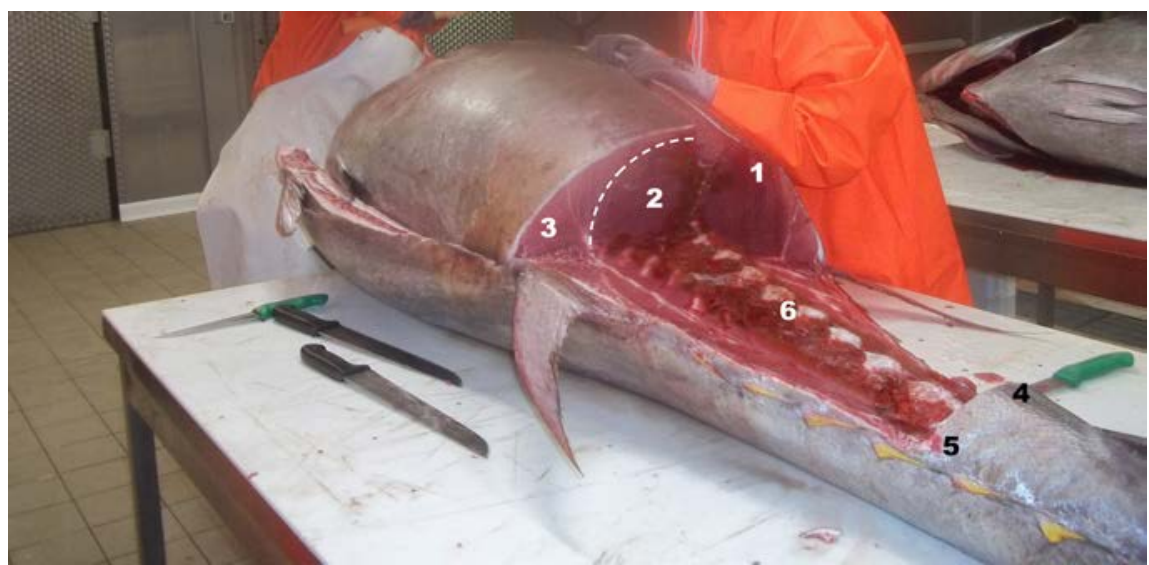

Figure 4. Intermediate processing step - at Tonnare Sulcitane's establishment - of bluefin tuna after removal of "codelle" or tails: 4) "nera" or black and 5) "bianca" o white on left fish side. In the transversal section, the far end of the following commercial cuts can be distinguished: 1) the "schienale" or upper loin; 2) the "bòdano" or lower loin, and 3) the "ventresca" or belly flap. In the deepest part alongside the fishbone, 6) the "buzzonaglia" or dark meat. since the corresponding protein binding sites distribute unevenly across tuna carcass. Whereas a certain degree of homogeneity could be a common feature to most of the fish species, large pelagic species, such as tuna, are characterised by distinct groups of muscular tissue categorized as white and dark edible tissue, instead. Moreover, specific studies (Balshaw et al., 2008) comparing the mercury content in the lean muscular tissue with higher fat content muscle, show lower mercury concentrations

The analytical results obtained from the different samples collected from the tuna lot of this case-study (including initial analysis carried out by official laboratory, private laboratory analysis on behalf of the food business operator, revision analysis and eventually analysis decided in case of arbitration procedures) do not allow conclusions supported by statistical significance because of sample size, although the relevant difference among such analytical results.

However, this case study reasonably induces to assume that also Northern bluefin tuna (Thunnus thynnus) is affected by an uneven distribution of mercury across carcass, as other inter-tropical species such as Yellowfin tuna (Bosch et al., 2016) or, more likely, other temperate and cold climate species such as Southern bluefin tuna (Balshaw et al., 2008).

Therefore, also in the present case there is potential for longitudinal variation causing discrepancies among different muscular cuts that European legislation managed by enforcing that the incremental sample must consist of the middle part of the fish. However, also a potential for transversal in the latter. 
variation (probably more remarkable than the previous one) must be considered as it could probably be caused by a dilution effect of the higher fat content in the front of the abdomen. In order to confirm such wellfounded hypothesis also for Thunnus thynnus, a specific study will be realized according to a proper sperimental method to obtain the required amount of analytical data to provide the necessary scientific evidence of variability of $\mathrm{Hg}$ distribution in such species. Indeed, when the mercury content of all commonly consumed cuts of tuna carcasses is to be considered in order to determine fitness for human consumption and verify compliance to statutory maximum levels, surely preparing and homogenizing composites of different white tissue cuts will produce the most reliable and robust estimate of mercury level in all of the white muscular tissue of one single fish. However, the large size of tuna species objectively makes producing of such composite samples per single fish time consuming and costly.

At present and in agreement with indication of mentioned studies (Balshaw et al., 2008; Bosch et al., 2016), it can be appropriate that instead of tissue composites, incremental samples taken from the anterior extremity of upper loin (or "schienale") are mainly representative of mercury (and lipid) content of all of the muscular tissue of each tuna fish in a lot.

\section{Conclusions}

Given that sampling errors can be minimized by ensuring that correct procedures are followed during field sampling (Maher et al., 1994), the sampling procedure to determine $\mathrm{Hg}$ level in tuna muscle, as reviewed and implemented by authors of this case-study, aims to provide an initial contribution in order to ensure an appropriate and representative field sampling protocol of tuna lots, by introducing more rigorous details including the identification of a specific muscular portion as sampling site.

On these grounds the authors intend to realize an experimental study - already started at closure of tuna catching season (end of June 2018) - in order to obtain the necessary sample size to provide the statistical significance to the hypothesis expressed by this case-study.

Furthermore, since sampling sites and subsampling methods could affect measurements to determine fitness for human consumption of tuna, and as acknowledged by other authors as well (Bosch et al., 2016), it would also be helpful that legislator issued more detailed guidelines on sampling procedure of large pelagic fishes to determine $\mathrm{Hg}$ contamination level.

\section{References}

Balshaw S, Edwards JW, Ross KE, Daughtry BJ, 2008. Mercury distribution in the muscular tissue of farmed southern bluefin tuna (Thunnus maccoyii) is inversely related to the lipid content of tissues. Food Chem 111:616-21.

Bonnaterre PJ, 1788. XVIII ${ }^{\mathrm{e}}$ Genre, Le thon: l'albacore (Thunnus albacares). In: Tableau enciclopédique et méthodique des trois règnes de la nature. Ichthyologie. Chez Pankouke Libraire, Paris, pp 139-43.

Bosch AC, O'Neill B, Sigge GO, Kerwath SE, Hoffman LC, 2016. Mercury accumulation in yellowfin tuna (Thunnus albacares) with regards to muscle type, muscle position and fish size. Food Chem 190:351-6.

Castelnau FL, 1872. Scombridae (Thunnus maccoyii). Contribution to the ichthyology of Australia. In: Proceedings of the Zoological and Acclimatisation Society of Victoria. Volume 1. F.A. Masterman, General Printer, Melbourne, pp 104-7.

Collette BB, Nauen CE (eds) 1983. Scombrids of the world. An annotated and illustrated catalogue of tunas, mackerels, bonitos and related species known to date. FAO Species Catalogue No 125, Volume 2. Published by arrangement whit the FAO of the ONU, Rome, pp 1-137.

Collette BB, Reeb C, Block BA, 2001. Systematics of the tunas and mackerels (Scombridae). In: Block BA, Stevens ED (eds) Tuna: physiology, ecology, and evolution. Chapter 1: I (Morphological systematics) and II (Molecular systematics). Academic Press, London, pp $1-33$.

EFSA, 2012. Scientific opinion on the risk for public health related to the presence of mercury and methylmercury in food. EFSA Journal 10:2985, pp 1-241.

European Commission, 2006. Setting maximum levels for certain contaminants in foodstuffs. Consolidated version of the Regulation (EC) No 1881/2006 of 19 December 2006. Official Journal of the EU, L 364:5-24.

European Commission, 2007. Laying down the methods of sampling and analysis for the control of the levels of trace elements and processing contaminants in foodstuffs. Consolidated version of the Regulation (EC) No 333/2007 of 28 March 2007. Official Journal of the EU, L 88:29-38.

Itano K., Sasaki S. 1983. Binding of mercury compounds to protein components of fish muscle. B Jpn Soc Sci Fish 49: 1849-1853 (original language: Japanese - translated (1984) by "Canadian Translation of Fisheries and Aquatic Sciences No. 5104 (http://www.dfompo.gc.ca/Library/89091.pdf).

Lee CS, Lutcavage ME, Chandler E, Madigan DJ, Cerrato RM, Fisher NS, 2016. Declining mercury concentrations in bluefin tuna reflect reduced emissions to the North Atlantic Ocean. Environ Sci Technol 50:12825-30.

Licata P, Trombetta D, Cristani MT, Naccari C, Martino D, Calò M, Naccari F, 2005. Heavy metals in liver and muscle of bluefin tuna (Thunnus thynnus) caught in the straits of Messina (Sicily, Italy). Environ Monit Assess 107:239-48.

Linnaeus C, 1758. Pisces thoracici (Thunnus thynnus). In: Systema naturae per regna tria naturae, secundum classes, ordines, genera, species, cum characteribus, differentiis, synonymis, locis. Tomus I, editio decima, reformata. Impensis direct. Laurentii Salvi, Holmiae, pp 260-302.

Lowe RT, 1839. Supplement to a synopsis of the fishes of Madeira. Family Scombridae (Thunnus obesus). In: Proceedings of the Zoological Society, part VII. Printed by Taylor, London, pp 77-80.

Maher WA, Cullen PW, Norris RH, 1994. Framework for designing sampling programs. Environ Monit Assess 30:13962.

Rasmussen RS, Nettleton J, Morrissey MT, 2005. A review of mercury in seafood: special focus on tuna. J Aquat Food Prod T 14:71-100.

Schaefer MB, Broadhead GC and Orange CJ, Robins JP, 1963. Synopsis of biological data on yellowfin tuna and southern bluefin tuna. In: FAO Fisheries Biology Synopsis Nos. 59-60, SAST - Tuna, Rome, pp 538-87.

Sharp GD, Pirages SW, 1978. The distribution of red and white swimming muscles, their biochemistry, and the biochemical phylogeny of selected scombrid fishes. In: Sharp GD, Dizon AE (eds) The Physiological Ecology of Tunas. Chapter 1 (The Tunas) III. Academic Press, London, pp 41-78.

Storelli MM, Giacominelli Stuffler R, Marcotrigiano GO, 2002. Total and methylmercury residues in tuna-fish from the Mediterranean Sea. Food Addit Contam 19:715-20.

Tiews K, Alverson FG and Peterson CL, 1963. Synopsis of biological data on atlantic bluefin tuna and bigeye tuna. In: FAO Fisheries Biology Synopsis Nos. 56-57, SAST - Tuna, Rome, pp 422-514. 